\title{
COMPUTERIZED TOMOGRAPHY FINDINGS IN FAHR'S SYNDROME
}

\author{
Andréia V. Faria, Inês C. Pereira, Livio Nanni
}

\begin{abstract}
We analyzed computerized tomography (CT) findings in six patients with Fahr's syndrome. They presented calcifications in basal ganglia, dentate nucleus, subcortical region and semioval center, due to alteration in calcium metabolism or due to senile relative hypoxemic state. The image pattern was not strictly related with etiology, although some differences in dystrophic senile calcifications (the only one present in semioval center and absent in subcortical region). CT is an easy exam, has maximum sensitivity and allows diagnosis, contributing to early treatment of many etiologies of Fahr's syndrome.
\end{abstract}

KEY WORDS: calcifications, computerized tomoghaph, Fahr's syndrome.

\begin{abstract}
Achados da tomografia computadorizada na síndrome de Fahr
RESUMO - Analisamos os achados de tomografia computadorizada (TC) de seis pacientes com síndrome de Fahr. Eles apresentaram calcificações nos gânglios da base, núcleo denteado, região subcortical e centro semi-oval, devidas a distúrbios no metabolismo do cálcio ou a estado de hipóxia relativa, por senilidade. O padrão de imagem não apresenta relação clara com a etiologia, apesar de algumas diferenças no caso das calcificações distróficas senis (as únicas presentes nos centros semi-ovais e ausentes na região subcortical). TC é um exame de fácil realização, máxima sensibilidade e permite o diagnóstico, contribuindo para o tratamento precoce de muitas das etiologias da síndrome de Fahr.
\end{abstract}

PALAVRAS-CHAVE: calcificações, sindrome de Fahr, tomografia computadorizada.

Fahr's disease refers to idiopathic calcification of the basal ganglia. This condition has been known since 1800s, many years before Fahr's description, in 1930, of a man with seizures and diffuse calcifications of the brain vessels and basal ganglia possibly due to hypoparathyroidism ${ }^{1}$. So, Fahr's disease might be considered a misnomer ${ }^{2}$, because Fahr's report was not the first one and does not describe idiopathic calcifications. Although this, the more general term Fahr's syndrome has been applied until today to describe a variety of pathological situations of many etiologies, that occur with basal ganglia calcification (BGC) without specific characterization by neuroradiology.

Clinical features are important because BGC may be viewed as an incidental finding. Headache, vertigo, movement disorders, paresis, stroke like events, cognitive impairment, psychiatric disorders, pyramidal signals and seizures are the most common manifestations ${ }^{3-6}$. Additionally, it has been stated that "pathological calcifications" exist when regions other than globus pallidus are involved".
This study was carried out to correlate pathological BGC, dentate nucleus and subcortical calcifications on computerized tomography (CT) with disease that caused them and to attempt to define systemic metabolic mechanisms of calcification formation.

\section{METHOD}

We selected and analyzed CT images of six patients with BGC and dentate nucleus, subcortical region and semioval center calcifications, performed with $2.5 \mathrm{~mm}$ slice in skull base and $5 \mathrm{~mm}$ slice in cerebrum.

\section{RESULTS}

Table 1 summarizes clinical and radiological aspects of the six patients. One patient (with 65 years old) did not present calcium serum alterations neither other associated disease. So, pathologic calcifications were attributed to senility. The five other patients presented disturbances in calcium metabolism (correlated with primary hypoparathyroidism in two, AIDS in two, and panhypoptuita-

Department of Radiology State University of Campinas (UNICAMP), Campinas SP, Brazil.

Received 9 December 2003, received in final form 25 March 2004. Accepted 13 May 2004.

Dra. Andréia Vasconcellos Faria - Departamento de Radiologia - UNICAMP - Caixa Postal 6111 - $13083-970$ Campinas SP - Brasil. E-mail: andreia@fcm.unicamp.br 
Table 1. Clinical and radiological aspects of patients.

\begin{tabular}{|c|c|c|c|c|c|}
\hline Patient & Sex & $\begin{array}{l}\text { Age } \\
\text { (years) }\end{array}$ & Calcification site & Associated disease & Clinical findings \\
\hline 1 & female & 68 & $\begin{array}{l}\text { Lentiform nucleus, caudate } \\
\text { and subcortical }\end{array}$ & $\begin{array}{l}\text { Panhypoptuitarism secondary } \\
\text { to Shehan's syndrome }\end{array}$ & Hypoglicemic crisis \\
\hline 2 & female & 23 & $\begin{array}{l}\text { Lentiform nucleus, caudate } \\
\text { and subcortical }\end{array}$ & Primary hypoparathyroidism & $\begin{array}{l}\text { Complex partial seizures } \\
\text { with secondary generaliza } \\
\text { tion, polineuropaty }\end{array}$ \\
\hline 3 & female & 65 & $\begin{array}{l}\text { Globus pallidus, semioval } \\
\text { center and dentate nucleus }\end{array}$ & Anyone detected & Headache and seizures \\
\hline 4 & male & 28 & $\begin{array}{l}\text { Lentiform nucleus, caudate, } \\
\text { subcortical, dentate nucleus } \\
\text { and thalamus }\end{array}$ & Primary hypoparathyroidism & Fasciculations \\
\hline 5 & female & 5 & $\begin{array}{l}\text { Lentiform nucleus, caudate } \\
\text { and subcortical }\end{array}$ & HIV infection & $\begin{array}{l}\text { Alteration in behavior } \\
\text { (aggressively) and weakness }\end{array}$ \\
\hline 6 & male & 7 & $\begin{array}{l}\text { Lentiform nucleus, caudate } \\
\text { and subcortical }\end{array}$ & HIV infection & $\begin{array}{l}\text { Global hypotonia without } \\
\text { choreo-athetotic movements }\end{array}$ \\
\hline
\end{tabular}

rism secondary to Shehan's syndrome in one). The symptoms were variable as motor deficits, seizures, comportment disturbances, headache and others. All patients presented calcifications in globus pallidus, five (with calcium disturbances) in caudate, lentiform nucleus and subcortical region, two in dentate nucleus, one (with senile dystrophic calcifications) in semioval center, and one (with hypoparathyroidism) in thalamus (Fig 1).

\section{DISCUSSION}

We present patients with pathological BGC, dentate nucleus and white matter calcifications of distinct etiologies and clinical features. This kind of abnormality is related with many etiologies that can be classified as inflammatory (CMV infection, neurocysticercosis, toxoplasmosis, neurobrucellosis, tuberculosis, HIV infection), tumoral (astrocytomas), hypoxic and vascular (arteriovenous malformations calcified infarct, ischemic encephalophaty), endocrine (hypoparathyroidsm, pseuso and pseudohypoparathyroidism, hyperparathyroidism), toxic ( $\mathrm{CO}$ and $\mathrm{Pb}$ intoxication, hypervitaminosis $\mathrm{D}$, radiotherapy), metabolic and degenerative (senility, mithocondrial encephalopaties, leukodistrophic diseases, idiopathic familial, motor neuron disease, myotonic muscular dystrophy, carbonic anidrase deficit, biopterin deficit) and other (malabsorption, Down syndrome, lupus, tuberous sclerosis, arthrogriposis) 8 .13.

Except by familial cause, with unknown mecha- nism, genetically determined, all other causes appear to result of calcium deposits by serum abnormalities (with a change in vascular permeability related to local calcium concentration $)^{14}$ or of dystrophic calcifications, with physical abnormalities in small vessel, focal circulatory disabilities and metabolic disorders (hypoxia, hypoglycemia, and abnormalities in the acid-base balance or electrolytes) ${ }^{15}$. Reduced blood flow to calcified regions is confirmed in SPECT of the brain with ${ }^{99 m}$ Tc-hexamethhylpropilenamine ( $\left.{ }^{99 m} \mathrm{Tc}-\mathrm{HMPAO}\right)^{16}$.

We report patients with pathological calcifications attributed to different etiologies: dystrophic (probable senile in one patient) and secondary to abnormal calcium metabolism (in two patients with hypoparathyroidsm). Both etiologies might be associated in patients with AIDS (because abnormal calcium levels are commonly associated with the disease ${ }^{17}$ and because they presented hypoxic episodes caused by pulmonary disease) and in the patient with panhypopitutarism (secondary to abnormal calcium levels and hypoglicemic crisis). The only difference noted in the calcifications pattern was their absence in subcortical region and basal nucleus and their presence in semioval center, in the patient with senile calcifications. Moreover, the patient with senile calcifications presented seizures and headache. Usually, the dystrophic form is silent or occur with extrapyramidal symptoms ${ }^{18}$. Since no associated disease was identified as responsible 


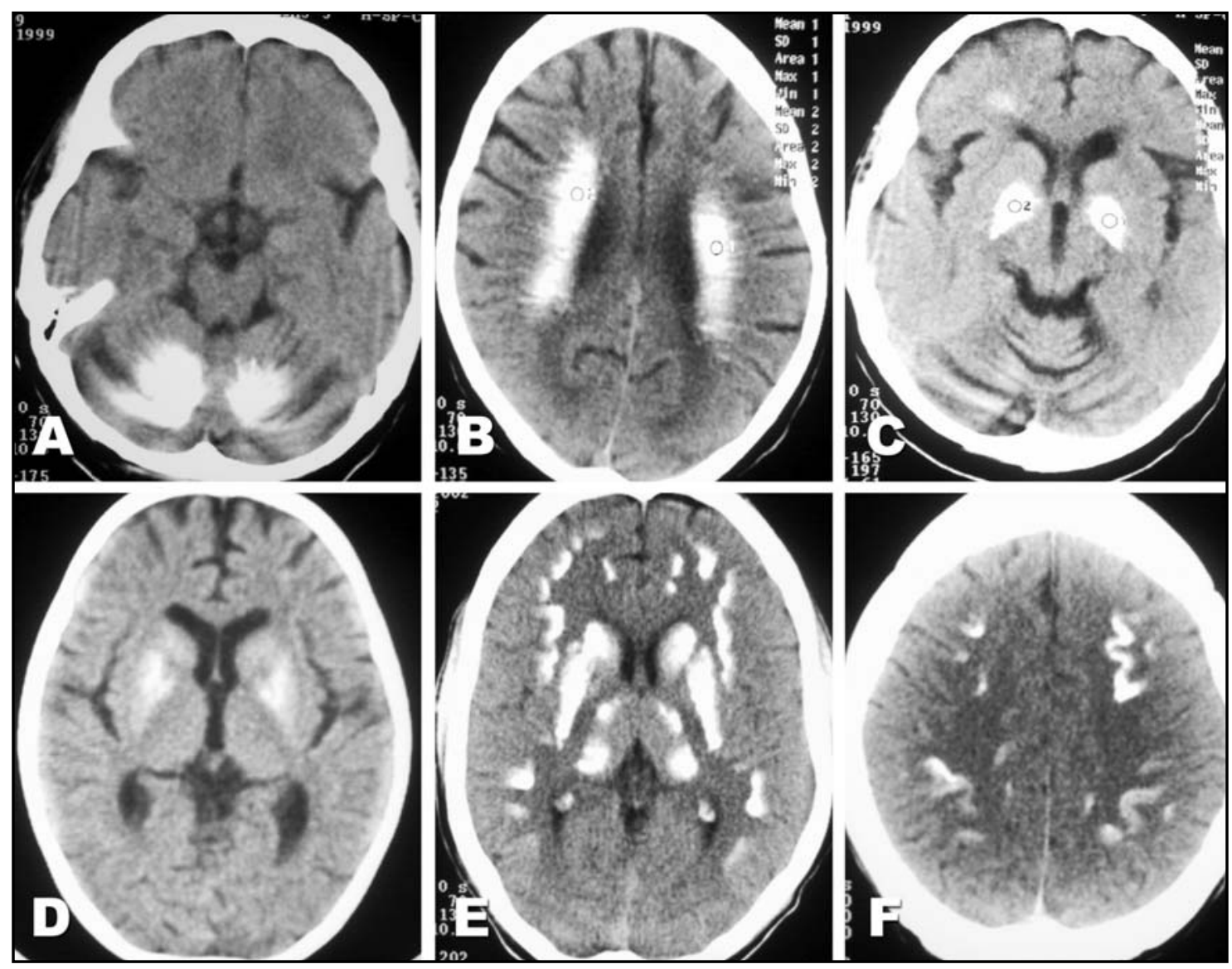

Fig 1. CT axial images show calcifications dentate nucleus and white matter of cerebellum (A), semioval center (B) and globus pallidus (C) in 65 years old with senile dystrophic calcifications. Basal ganglia calcification (D) is found in a patient with AIDS. Diffuse calcification in basal ganglia $(E)$ and subcortical region $(E$ and $F)$ is shown in patients with hipoparathyroidism and hypopituitarism, respectively.

by these clinical features, in agreement with previous studies ${ }^{7}$ we suppose that dystrophic calcifications in other places than globus pallidus (for example, dentate nucleus and semioval center as occurs in this patient), are related to other symptoms in adults (particularly to psychiatric disorders) ${ }^{19-21}$.

Because it involves many etiologies, it is difficult attribute neurological deficits as cause or consequence of Fahr's syndrome. Classical and recent anatomical studies about the role of basal ganglia in movement coordination ${ }^{22}$, subcortical region in cognitive association and mood determination, and hypoxia in epileptic activity ${ }^{23}$, points to correlation between clinical features and calcifications site and consequently hypoperfused area ${ }^{7,10}$.

Recognition of the intracranial calcifications in Fahr's syndrome has been made easier by the high resolving capability of CT. Calcifications consist of hydroxyapatite of a nature similar to that found in bones. Other elements include zinc, iron and magnesium ${ }^{24}$. Because this material composition, they are always hyperdense on $\mathrm{CT}$. On magnetic resonance imaging (MRI), however, their signal is variable. On T1 weighted images, low signal is due to the low proton density of calcium and other mineral ions present in higher concentration. However, they might present hyperintense signal, due to proteins and mucopolysaccharides binding the mineral ions. They might also to be undetected on MRI when are in a intermediary stage ${ }^{25}$.

In conclusion, Fahr's syndrome is manytimes a treatable entity. Etiology is not directly correlated with image calcification pattern, except for some differences noticed in calcifications site in dystrophic senile ones. Topographic image studies are promising to predict neurological deficits. Their recognition by $\mathrm{CT}$ is easy, has maximum sensitivity and may be responsible by early treatment. 


\section{REFERENCES}

1. Klein C, Vieregge P. Fahr's disease: far from a disease. Mov Disord 1998;13:620-621.

2. Manyam BV, Walters AS, Keller IA, Ghobrial M. Parkinsonism associated with autosomal dominant bilateral striopallidodentate calcinosis. Parkinsonism Relat Disord 2001,7:289-295.

3. Konig P. Psychopathological alterations in cases of symmetrical basal ganglia sclerosis. Biol. Psychiatry 1989;25:459-468.

4. Vega MG, Souza AA, de Lucca F, Purich S, Tenassi ML. Síndrome extrapiramidal e hipoparatireoidismo: acerca da identidade da doença de Fahr. Arq Neuropsiquiatr, 1994,52:419-423.

5. Cavalcanti CE. Cisticercose calcificada em gânglios da base e síndrome parkinsoniana. Arq Neuropsiquiatr 1984;42:183-186.

6. Levy G. Basal ganglia calcification (striopallidodentate calcification) and cognitive impairment. Arq Neuropsiquiatr, 1999:57:148.

7. Harrington MG, Macpherson P, Mcintosh WB, Allam BF, Boné I. The significance of the incidental finding of basal ganglia calcification on computed tomography. J Neurol Neurosurg. Psychiatry. 1981;44:1168-1170.

8. Perez MA, Martin PE, Sarmiento GE, et al. Farh's disease and hypocalcemic syndromes: presentation of a clinical case. An Med Interna 1992;9:495-497.

9. Diament AJ, Machado LR, Cypel S, Ramos JLA. Síndrome de calcificações dos gânglios da base, leucodistrofia e pleocitose linfomonocitária crônica de líquido cefalorraquidiano. Arq Neuropsiquiatr 1986,44:185-190.

10. Delgado-Rodrigues RN. Neurocisticercose associada a hipoparatireoidismo e doença de Fahr. Arq Neuropsiquiatr. 1984,42:388-391,

11. Rocha C, Gonfinitti NV, Pelucci LA. Aspectos clínicos e radiológicos do pseudo-hipoparatireoidismo. Arq Neuropsiquiatr 1997;55:139-143.

12. Guerreiro MM, Scotoni AE. Calcificações dos gânglios da base na infância. Arq Neuropsiquiatr, 1992;50:513-518.

13. Queiroz AC, Malboisson AMB. Calcificações nos núcleos da base do cérebro. Arq Neuropsiquiatr. 1981;39:321-326.

14. Brannan TS, Burger AA, Chaudhary MY. Bilateral basal ganglia calcifi- cations visualised on CT scan. J Neurol Neurosurg Psychiatry. 1980; 43:403-406.

15. Ogi S, Fukumitsu N, Tsuchida D, Uchiyama M, Mori Y, Matsui K. Imaging of bilateral striopallidodentate calcinosis. Clin Nucl Med 2002; 27:721-724.

16. Uygur GA, Liu Y, Hellman RS, Tikofsky RS, Collier BD. Evaluation of regional cerebral blood flow in massive intracerebral calcifications. J Nucl Med 1995;36:610-611.

17. Fenelon G, Gray F, Paillard F, et al. A prospective study of patients with CT detected pallidal calcifications. J Neurol Neurosurg Psychiatry 1993;56:622-625.

18. Barbosa ER, Culchebachi MDB, Navarro JM, Scaff M, Canelas HM. Lesões hipoatenuantes dos gânglios da base associadas a quadro pirâmido-extrapiramidal. Arq Neuropsiquiatr 1986;44:55-59.

19. Ostling S, Andreasson LA, Skoog I. Basal ganglia calcification and psychotic symptoms in the very old. Int J Geriatr Psychiatry 2003;18:983-987.

20. Cartier L, Passig C, Gormaz A, Lopez J. Neuropsychological and neurophysiological features of Fahr's disease. Rev Med Chil 2002;130:1383-1390.

21. Warren JD, Mummery CJ, Al-Din AS, Brown P, Wood NW. Corticobasal degeneration syndrome with basal ganglia calcification: Fahr's disease as a corticobasal look-alike? Mov Disord 2002;17:563-567.

22. Hempel A, Henze M, Berghoff C, Garcia N, Ody R, Schroder J. PET findings and neuropsycological déficits in a case of Fahr's disease. Psych Res 2001;108:133-140.

23. Petroff OAC, Errante LD, Kim JH, Spencer DD. N-acetyl-aspartate, total creatine, and myo-inositol in the epileptogenic human hippocampus. Neurology 2003;60:1646-1651.

24. Smeyers-Verbeke J, Michottey Y, Pelsmoeckers J, et al. The chemical composition of idiopathic non ateriosclerotic cerebral calcification. Neurology 1975;25:48-57.

25. Scotti G, Sciafla G, Tampieri D, Landoni L. MR imaging in Fahr disease. J Comput Assist Tomogr1985;9:790-792. 